Meta

Journal des traducteurs

Translators' Journal

\title{
Stories Travelling Across Nations and Cultures
}

\section{Patrick Cattrysse}

Volume 49, numéro 1, avril 2004

Traduction audiovisuelle

Audiovisual Translation

URI : https://id.erudit.org/iderudit/009018ar

DOI : https://doi.org/10.7202/009018ar

Aller au sommaire du numéro

\section{Éditeur(s)}

Les Presses de l'Université de Montréal

\section{ISSN}

0026-0452 (imprimé)

1492-1421 (numérique)

Découvrir la revue

Citer cet article

Cattrysse, P. (2004). Stories Travelling Across Nations and Cultures. Meta, 49(1), 39-51. https://doi.org/10.7202/009018ar

\section{Résumé de l'article}

Les producteurs de films européens ont souvent déclaré que la diversité linguistique représente l'obstacle le plus important pour que les films européens traversent les frontières nationales et culturelles avec succès. Certains ont même essayé de nous faire croire qu'il suffirait de produire des films en anglais pour garantir un succès international. Dans cet article, on suggère que l'emploi efficace de certaines techniques rhétoriques peut jouer un rôle plus important et augmenter les chances qu'une narration filmique voyage avec succès au-delà des frontières. Une étude comparative approfondie de la présence ou de l'absence de ces techniques rhétoriques et du choix linguistique, appliquée à un corpus spécifique de films européens, pourrait nous éclairer sur l'importance relative des paramètres respectifs dans le cadre de la discussion plus générale des films européens exportés et de la politique traductionnelle suivie. 


\title{
Stories Travelling Across Nations and Cultures
}

\author{
PATRICK CATTRYSSE \\ Flanders Script Academy, Heverlee, Belgium \\ patrick.cattrysse@skynet.be
}

\begin{abstract}
RÉSUMÉ
Les producteurs de films européens ont souvent déclaré que la diversité linguistique représente l'obstacle le plus important pour que les films européens traversent les frontières nationales et culturelles avec succès. Certains ont même essayé de nous faire croire qu'il suffirait de produire des films en anglais pour garantir un succès international. Dans cet article, on suggère que l'emploi efficace de certaines techniques rhétoriques peut jouer un rôle plus important et augmenter les chances qu'une narration filmique voyage avec succès au-delà des frontières. Une étude comparative approfondie de la présence ou de l'absence de ces techniques rhétoriques et du choix linguistique, appliquée à un corpus spécifique de films européens, pourrait nous éclairer sur l'importance relative des paramètres respectifs dans le cadre de la discussion plus générale des films européens exportés et de la politique traductionnelle suivie.
\end{abstract}

\begin{abstract}
European filmmakers have often stated that linguistic diversity presents the major obstacle for European movies to cross national and cultural borders successfully. Some have even tried to make us believe that it would suffice to produce a movie in English to guarantee its international success. This article suggests that the effective use of some specific rhetorical devices might play a more important role in enhancing the chances of filmic narratives to travel successfully across nations and cultures. A thorough comparative study of the presence or absence of these rhetorical features and the use of language, applied upon a specific corpus of European movies, could enlighten us on the relative importance of the respective parameters within the larger discussion of movies travelling across nations and cultures and various translation policies.
\end{abstract}

\section{MOTS-CLÉS/KEYWORDS}

audience, film narrative, film production, global/local success, interdisciplinarity

\section{Introduction}

The study of the international and cross-cultural potential of narrative movies fits into the larger context of globally successful storytelling. This matter has been approached from many sides, especially with respect to the disadvantageous market position of European movies as opposed to the American ones. Producers have stated they needed more money to compete with the larger American budgets. Distributors have repeated the same request to make European movies more accessible to the public. So has the exploitation sector based on the argument that the development of multiplex cinema theatres and the proliferation of outlets for films raised Europeans' hopes for a wider choice in the cinemas. From the point of view of screen translation, the role of language has been questioned, and more specifically, the role of subtitling and dubbing. More often than not, Europe has advanced its linguistic diversity as another handicap inhibiting movies from travelling successfully across 
national borders. In a contribution entitled Shooting in English? Myth or Necessity?, Jäckel (2001:73) quotes the 1992 Seminar on "The Challenge of Language in European Film" pointing at:

Those European producers who had decided to make a film in English (regardless of the demands of the subject matter) as a sure-fire way to international success ending up with the most abysmal critical and commercial failures ever to inflict themselves on the international market (BSAC 1992:7) ${ }^{1}$.

Clearly, it is not enough to produce a movie in English to guarantee its success on a global scale. Neither will subtitling or dubbing a movie in English guarantee international and cross-cultural success. The question of the bestseller and the globally successful story is probably as old as storytelling itself. What makes a story effective or successful, nationally or internationally, represents a complex set of parameters that vary in time and space, and produce whatever is understood by success in one specific hic et nunc situation. Even after the fact, it is often very difficult to explain why a narrative succeeded or failed. If we want to grasp the relevance of subtitling, dubbing and the choice of language in general within this larger context of globally successful storytelling, we need to understand the role and importance of some other players in this game.

\section{Successful storytelling}

Successful or effective storytelling is a problematic concept because it conveys different meanings to different people. In communication studies, scholars often link successful versus unsuccessful communication with communicational objectives and respective target groups. Effective communication is then measured on the basis of succeeding versus failing, entirely or partially, to achieve the objectives with respect to the targeted audience. Commercial box office represents one example of effective storytelling. Obtaining critical artistic recognition in the right journals and at specific festivals can be another one. Producing a specific type of aesthetic pleasure upon a specific audience constitutes a third specific objective that can be strived for and reached or not.

In what follows, I focus on mainstream narrative cinema, that is, filmic storytellers aiming at reaching the appreciation of a larger audience. Furthermore, I hereafter consider the trans-national and cross-cultural potential of narratives from the even more restricted point of view of the storyteller (or screenwriter). In what follows, I advance the hypothesis that the presence or absence of specific rhetorical devices in texts co-determines the choices that are made with respect to the relocation of meaning (cf. Vandaele 1999) of said texts. I confess that henceforth, I shall ask more questions than I can answer. To me, they represent the beginning of a more extensive, systematic, empirical research program in which the choice of language, and particularly the choices of subtitling and dubbing are considered next to other types of relocation of meaning (e.g. remake, adaptation, ...) and within the larger context of international and cross-cultural filmic communication. In order to prove or falsify that hypothesis, one has first to learn what features we are talking about. 


\section{What are rhetorical features?}

Since Aristotle, scholars have defined rhetorics in many different ways. The discipline as well as the practice is more than two thousand years old. In trying to come to terms, Chatman (1990:203) argues that

Rhetoric $[\ldots]$ should refer rather specifically to end-oriented discourse, where "end" is conceived as the suasion of the audience.

Bordwell (1991:34) concurs: "Rhetoric, classically conceived, is concerned only with persuasion, not truth." But what is it that the audience is suaded to do? "What is the end of a rhetoric (that is, practice) of fiction?"' Chatman (1990:187) asks. In the preface of his The Rhetoric of Fiction, Wayne Booth suggests:

The rhetorical resources available to the writer of epic, novel, or short story as he tries, consciously or unconsciously, to impose his fictional world upon the reader (Booth 1991:xiii).

The verb "to impose" remains vague. What does it mean when an author tries to impose his fictional world upon the reader? Speaking of Henry James, Booth (1983:ibid.) explains that "the ostensibly rhetoric move [...] is dictated by the effort to help $p^{2}$ (sic!) the reader grasp the work." According to Seymour Chatman, writers want "to involve us in their fictional world" (Chatman 1990:187). Rhetorical devices induce the hearts and the minds of an audience to follow a narrative through to its conclusion, and to enjoy it. To that end, "a central purpose of fictions is to create their own believable worlds, imaginary spaces containing plausible (or at least self-consistent) characters and actions" (Chatman 1990:189). Also, rhetorical devices are "the means by which the writer makes known his vision to the reader and persuades him of its validity" (Chatman 1990:190). And finally, novelists solicit "the reader's acceptance of the validity of the way the novel is put together regardless of what the novel is about" (Chatman 1990:188). Hence, the scholar concludes:

The expression "rhetoric of fiction" [...] best refers to a fiction's suasion that its unfolding form be accepted (Chatman 1990:188).

Chatman (1990:200) mainly speaks of "writers," "readers" and literary fiction³. I prefer the concepts author (collective or individual) and audience or perceiver (cf. infra), since they apply to any type of semiotic behaviour.

This limited number of specifications already permits us to draw some conclusions. The study of rhetorics obviously transcends the immanent text. It involves the entire communication process: Sender/Author (collective or individual) - Message Perceiver/Audience. The descriptions quoted above mainly hint at specific devices, which can be detected within the text -, and their respective effects, - which can be detected within the audience(s) - . Only a study of the audience, it would seem, can prove whether certain rhetorical devices have helped the audience to grasp the work, whether they have induced the hearts and the minds of that particular audience to follow a narrative through to its conclusion, and to enjoy it.

If we want to examine the possible relationship between the presence/absence of specific rhetorical devices within a text (literary or filmic) and its potential or realised types of "translation," it will be impossible to ignore the rhetorical effects of said devices upon the targeted audience(s). 


\section{Rhetorics and the real audience}

To acknowledge a real audience, however, oftentimes seems to represent a problem, not only among artists, but also among scholars. "True Art Ignores the Audience." Thus begins Wayne Booth's (1983) fourth chapter in Part One:

True artists, we have been told again and again, take no thought of their readers. They write for themselves. The true poet writes to express himself, or to find himself, or "to get rid of the book" - and let the reader be damned (Booth 1991:89).

Booth observes that it is only in handbooks about how to write best sellers, that one finds open advice to the author to think of his reader and write accordingly.

The predominant fashion among serious writers has been to consider any recognizable concern for the reader as a commercial blemish on the otherwise spotless face of art. If someone is rude enough to ask who the serious writers are, the answer is easy: they are those whom one could never suspect of writing with the reader in mind (Booth 1991:90).

For an artist to consider the audience is problematic because it contaminates the purity of the art. In the first part of his book, "Purity and Rhetoric," Booth (1991) explains that therefore modern novelists consider any reference to extra-textual material as involving impurity. In this respect, Booth (1991:95) speaks of the inherent "impurity" of literature because of its inevitable reference to a reality that is "outside." Yet, at the same time, he notices some troubling contradictions:

Unlike many modern aestheticians, Aristotle never completely repudiates the rhetorical dimension of poetry. He clearly recognizes that one thing the poet does is to produce effects on audiences. In exciting feelings "such as pity, fear, anger, and the like," and in suggesting "importance or its opposite," poetry is, in fact, closely related to rhetoric (Booth 1991:92).

Furthermore, Booth (1991:98) continues, what is one to say about the impurity of some literary works that are generally considered to be great?

If the most admired literature is in fact radically contaminated with rhetoric, we must surely be led to ask whether the rhetoric itself may not have had something to do with our admiration (Booth 1991:98-99).

And hence, Booth concludes that, if we object to everything directed at the audience's emotional reactions,

if recognizable appeals to the reader are a sign of imperfection, perfect literature is impossible to find; in the great works, not just of fiction but of all kinds, we find such appeals wherever we look.

Thus: the author cannot choose to be rhetorical or not, only how rhetorical to be.

In filmmaking, we encounter a parallel discussion. "Serious" filmmakers want to express themselves, want to be original, different, no matter what. As a consequence, they often ignore the audience. That is why in his screenwriting manual Story, McKee (1997:7) 7) stresses the point over and again that "effective" storytelling is about "respect, not disdain, for the audience." That is also why in his editorial of ScriptWriter, Friedman (2002:5) opens with the title: "On not writing only for yourself."

As Booth already suggested above, the question of rhetorics and the audience is linked with the discussion about high versus low culture, art versus commerce ${ }^{4}$. 
Effective communication reaching successfully larger audiences is labelled "commercial," and the label "commercial" is generally considered to be incompatible with labels such as "artistic," "serious" or "high culture." Commercial successes, which are also critical successes, are then considered to be the exceptions that confirm the general rule.

The disdain for the real audience finds its parallel in scholarly practice. Since the late 1960's, studies have appeared in reader-response-criticism and reception theory. These studies shifted the attention from the text towards the constructive role of the perceiver, that is, the interpretation process or the process of making meaning. However, within this type of studies, many scholars examined the process of semiosis with respect to themselves rather than to a real empirical audience. In doing so, they confused the subject and object of the study. In order to confine the analysis to the textual characteristics, scholars created concepts such as implied author and implied audience. If we reconsider the rhetorical effects mentioned above: to help the audience grasp the work, to involve the audience, to make it enjoy, these objectives are pointless when directed towards an implied audience. I believe that when writing about these effects, Booth (1991) is thinking real effects upon real readers. In his Rhetorical Narratology, Michael Kearns (1999) agrees with this position. He too is interested in "analyzing the interplay between texts and contexts in order better to understand how audiences experience narratives" (cf. Kearns 1999:2). He therefore proposes

a rhetorical narratology that is grounded in speech-act theory and thus considers narrative from the perspective of the socially constituted actions it performs: narrative as "doing" as well as "saying" (Kearns 1999:ibid.).

Later on, Kearns (1999:84) confirms that "it is also central to the rhetoric of narrative how audiences and narratives interact." Unfortunately, Kearns' study limits its audience-study to himself, his students and his children...

Chatman (1990) on the other hand clearly dissociates himself from this line of research. He is very anxious to keep the analysis within its textual borders. He redefines the term suasion and to suade, as opposed to to persuade, in order to:

Emphasize [...] that rhetoric concerns the urgings of the text, the "available means," rather than its ultimate success or failure with real audiences. Rhetoric, in this sense, has nothing to do with public opinion polls. The practical effect of texts on public attitudes is more properly a subject for the social sciences.

I agree that rhetorical features are textual. They can refer to "available means." I am sceptical, however, when scholars test the "urgings" of a text solely upon themselves. One can only examine if "available means" actually "urge" someone by testing real, that is empirical audiences. To conclude that "the practical effect of texts upon public attitudes is more properly a subject for the social sciences" represents another unfortunate stab at integrated, interdisciplinary research. Hence, contrary to Chatman's point of view, I plead for an interdisciplinary approach studying textual features as well as their hic et nunc effects upon real audiences. This implies integrating more thoroughly the knowledge and expertise of different disciplines: not only narratology, rhetorics, semiotics, linguistics, cultural studies, but also other disciplines such as communication studies, social sciences, statistics, psychology, cognitive studies, neuro-biology, etc. 


\section{What features are we talking about?}

If we accept that the concept of aesthetic pleasure refers to the motivation of an audience to watch a movie or theatre play, or read a novel through to its end, then we must also accept that there are many reasons why people can appreciate a movie, a theatre play or a novel. Talking about tragedy, Aristotle was already trying to discern different levels of aesthetic pleasure. In his Poetics (330-350 B.C.), he distinguishes between plot, character, spectacle 5 , argument, theme and music. These levels refer to text-immanent characteristics. One could add other "external" factors such as publicity, contests and prizes to win, etc. These external factors may help attract people into the cinemas. Whether they play a role in the type of aesthetic pleasure the audience experiences while watching the movie remains questionable 6 .

As stated above, I limit the discussion to the main responsibility of the screenwriter, that is plot and character, although theme and argument are also of great importance, and screenwriters may have an indirect influence on the spectacle-level by their selection of settings (cf. arena).

The rhetorical "features" I am referring to stem from a multitude of manuals and training programs on "How to write successful stories." Most of the manuals were published since the 1980's. Most of them are American. That is why, mistakenly, these features are often presented as American. In fact, they are more than two thousand years old and are of Roman and Greek origin. In what follows, I only sketch some examples.

Some basic components of drama are often expressed with the mnemonic phrase Who wants what very badly and why can't he? "Who" refers to the protagonist of the narrative. "Wants what" represents the dramatic goal. "Very badly" suggests what is sometimes called the "or-else" factor. And "Why can't he" refers to the antagonist, the main conflict of the story and the obstacles.

One problem with many of these mnemonic phrases is their apparent simplicity. This simplicity may stem from the many centuries of oral and written tradition. It is however deceptive. Behind this "simple" question of "who wants what..." lie a number of strategies that have withstood many centuries of empirical testing. A ten page article is not the best place to fully explain these strategies. Still, in what follows, I intend to show that these apparently formulaic rules actually represent strategies that are rhetorical in nature: they aim at specific effects upon real audiences. Also, a better understanding of these strategies will clarify why it might be possible that their presence or absence in narratives co-determines the local or global functioning of those same narratives.

Generally, the argument starts with the observation that audiences are more interested in people than in general causes or subjects. A story about politics, economics or social circumstances will generally interest less people then a story about Robert or Kathy. This does not mean that abstract content material cannot be part of the subject matter or theme of the narrative. Experience shows however that these abstract subjects have a better chance of successfully reaching a larger audience if they are integrated or translated into a story line that deals with concrete persons: e.g. Robert and Kathy struggling with political, economical or social problems. That is why training programs suggest working with a protagonist or main character. A protagonist or main character helps the audience to empathise with (part of) the narrative. 
One could say that the Bob character is the protagonist in Ken Loach's Raining Stones.

Furthermore, experience shows that audiences are more interested in people who want something than in people who do not want anything. It is very hard to tell a compelling story about somebody who does not want anything. A story about somebody who wants something has more chances to interest a larger audience. Manuals use the term dramatic goal. In Raining Stones, Bob's dramatic goal consists in buying a communion dress for his little daughter.

If the objective of the narrative consists in involving an audience, it is important to make the dramatic goal convincing. The word convincing, however, is a tricky concept. It means that it should convince the audience to sit through the narrative, be interested and enjoy it till the end. One way of trying to achieve this consists in showing that the dramatic objective is important to the protagonist. If the main character does not think his dramatic goal is important, there is a big chance the audience will not think it is either. Why then should it be interested in following the character on his narrative track towards his dramatic goal?

The term convincing does not necessarily mean that the dramatic goal is spectacular or grand scale. The spectacular or un-spectacular nature of the dramatic goal will depend rather on the type of story that is told (cf. genre norms). In a James Bond movie, the dramatic goal will be nothing less than the salvation of the world. In Raining Stones, Bob's dramatic goal is much less spectacular, though by no means less important. In fact, one might suspect Bob's dramatic goal to be much more important to him than the salvation of the world is to James Bond.

With respect to the convincing nature of the dramatic goal, manuals often distinguish three types of protagonists. Protagonists can be active, re-active and passive. It stands to reason that it will be easier to convince the audience of the importance of the dramatic goal if the protagonist is active or re-active. In other words, it will be more difficult to convince the audience of a dramatic goal with a passive protagonist, that is, with a character that does not take any action to achieve that dramatic goal. If a character pretends to want something very badly but does not act upon it, it will be very hard to convince the audience that this "want" is important to the character. If the dramatic goal is not important to the main character, why should it be to the audience?

In order to help the writer think further about the convincing nature of the dramatic goal, training programs suggest the creation of what they call an or-else factor. The or-else factor refers to the imminent misfortune that will happen if Protagonist does not achieve his dramatic goal. In the case of James Bond, the or-else factor is obvious: the end of the world. In Raining Stones, Bob must buy a communion dress for his little girl, because if he does not, he and his family will be excluded from their friends and social surroundings. His little girl might not be able to talk to her friends again. In fact, she might be expelled from school, since the communion represents an essential ceremony in this Irish Catholic setting.

A fourth dramatic component, the antagonist, helps to further develop the convincing nature of the dramatic goal. It is based on the experience that for something to be considered important or highly valuable, it cannot be thrown into one's lap without a struggle or a fight. This statement joins a very old adagio: drama is conflict. In order for the main character not to reach his dramatic goal from the very beginning, 
it helps to introduce a character whose objective is directly opposed to that of the main character, and who is willing to do anything in her or his power to prevent the protagonist from achieving his dramatic goal.

The antagonist (among other dramatic players) provides a fifth basic dramatic component: the main conflict and the obstacles. They make sure that the narrative does not end before it really starts. Suppose Paul tells Paulette that he loves her very much and that he wants to marry her, and she immediately says: "ok" and they live happily ever after. There would hardly be a compelling narrative. The main conflict and the obstacles also give the protagonist a chance to struggle for his valuable dramatic goal. At the same time, they give the writer the chance to develop a story that is not finished before it starts.

As stated before, it is impossible to present a complete course in effective storytelling in ten pages. Besides these basic dramatic components, there are many other devices dealing with structure and the distribution or the withholding of information, which serve similar rhetorical purposes. Some examples include specific techniques in character development, structural features such as the teleological nature of the narrative, its evolution in crescendo and the use of the so-called jigsaw structure, which are related to the strategic distribution of obstacles within the narrative, and the avoidance of episodic structures. A teleological structure refers to a strong causal relationship between events. It strengthens viewer or reader motivation. The audience understands better why events take place and understanding enhances empathy. The crescendo structure is related to the common principle that one should save the best for last. The principle can be applied in numerous ways: often, it means that the obstacles become more and more important and that the protagonist must increase his efforts to reach his dramatic goal. An episodic narrative presents episodes, that is narrative units each containing a beginning, middle and end. After each episode, a new story line has to start up. One can easily recognise a summative structure within a narrative when the order of its events can be permutated without plot related consequences. These episodic and summative structures loosen viewer interest; indifference becomes imminent. Narratologists refer to the policy of distribution or withholding information with the term point of view or focalisation (Bal 1999:142ff.). The choice of one particular type of focalisation in itself does not indicate any rhetorical preference or objective. Rather its functional use in one particular hic et nunc situation does (cf. Chatman 1990:195). Rhetorical uses of focalisation can be found in narrative techniques such as dramatic irony, - where the viewer knows more than the character - the twist or the reversal, - where the chararcter(s) know more than the audience. Whereas the former device can create suspense, the latter can provoke a surprise.

\section{Rhetorical nature of these features}

Before tackling the relation between the presence or absence of these features and possible ways of "translating" filmic narratives, I want to stress the importance of considering these features as rhetorical devices ${ }^{7}$. Until now, too often, these features have been misunderstood and mispresented. And I suspect that oftentimes the discussion has not been fair also because of political purposes in cultural warfare. Artists as well as scholars have often discarded the use and study of rhetorical strategies such as 
those mentioned above with the argument that they reduce the narrative potential to a limited number of formulaic stories. Even such a short explanation as mine given here should indicate that this amounts to saying that since we only have twenty-six letters, or since our linguistic system has only forty some phonemes, we shall all have to say the same things. It should be clear that, just like the letters of an alphabet or the phonemes of a linguistic system, the rhetorical devices described above are content independent. As Chatman (1990:188) already suggests, they refer to the way the narrative is put together, - Chatman uses the word form (cf. supra) -, much more than to what the narrative is about. Hence, applying these devices in no way forces storytellers to tell the same formulaic story over and over again. On the contrary, my suggestion is to consider them rather like a set of possibilities, - not unlike the rules of grammar -, offered by a specific system of communication. These strategies are meant to help communicators communicate in a more effective way; they are meant to increase the chances that the targeted audience will understand their communication. They are simply help tools for the writer to construct a convincing answer to the audience's question: "Why should I watch and appreciate this movie till the end"? Hence, with Chatman's and Booth's description of rhetorics in mind (cf. supra), the devices described above clearly fulfil a rhetorical function. Their very purpose consists in:

- Helping the audience grasp the narrative;

- Involving the audience in the fictional world;

- Inducing the hearts and the minds of the audience to follow the narrative through to its conclusion, and to empathise with its story;

- Creating believable worlds, with imaginary spaces and containing plausible (or at least self-consistent) characters and actions.

\section{Rhetorical features and local vs. global success?}

I realise that from here on, I am walking on thin ice. I therefore ask the reader to consider the following as "working hypotheses-to-be-verified."

Also, for a good understanding, I repeat that there are many reasons why people appreciate a movie; in other words, there are many levels of aesthetic pleasure. For practical purposes, I have narrowed my scope down to the point of view of the screenwriter. I focus on devices related to plot and character, and I consider spectacle, theme, subtext and values indirectly. For the sake of convenience, I call this level the narrative level. I therefore do not consider music, photography, casting and stardom, nor do I study other features at other levels although they too can convince an audience to sit through a movie and enjoy it. One must therefore always keep in mind that while the following considerations are located on this one narrative level, other devices and effects at other levels of aesthetic pleasure can compensate and codetermine a movie's functioning within a specific time-space context.

Having said this, one can imagine that, since the very purpose of the rhetorical features described above consists in convincing the audience to sit through a movie and empathise with its narrative, the effective use of these techniques contributes to a large extent to the success or failure of that movie on its narrative level. This success or failure may be domestic as well as international. As stated above, the rhetorical features mentioned above are subject independent, and therefore also language independent. It would therefore be interesting to examine whether a movie's chances to 
cross national and linguistic borders successfully is not less dependent on a narrative's language than on the convincing nature of the rhetorical devices applied by the writer.

Cultural studies have shown that national and linguistic borders do not necessarily coincide with cultural borders. Hence, it would also be interesting to examine to what extent the rhetorical devices are universal or not on a cultural level. To what extent, where and when for example, are audiences more interested in:

- Stories about people rather than stories about ideas or notions (cf. protagonist);

- Characters who want something rather than characters who do not want anything (cf. dramatic goal);

- A dramatic goal they find worthwhile (cf. or-else factor);

- A dramatic goal that is not obtained without a struggle or by coincidence (cf. antagonist and obstacles).

To what extent, where and when, do teleological structures that develop in crescendo offer audiences more chances to empathise with the narrative or not. And so on.

Within the study of the local and the global, a distinction often applied by manuals may be useful; I mean the distinction between story line on the one hand, and premise or theme on the other ${ }^{8}$. Again, many definitions are in use. I pick one.

[Theme is] the universal statement the screenplay makes about the human condition. This is a level of meaning that goes beyond the plot of the film and applies to life in general. The theme is an idea that any member of the audience can apply to her own life, whether or not she's been in a similar situation (Hauge 1991:32-33).

Hauge feels certain about the universal efficiency of theme ${ }^{9}$. I would prefer to add a question mark to this statement and consider it as another hypothesis. Simplifying matters, one can say that in general, the story line offers an example, an illustration, some kind of concretisation of the more general but underlying theme or premise. One could say that often, the story line offers what Aristotle calls the argument to convince the audience of the underlying theme or premise or message. Whereas the plot and the characters of the story line may be local, the underlying theme and values may be global, or at least acceptable to larger parts of the world. The American western is a good case in point: a local story line translating global values. Storytelling therefore could be considered internationally and interculturally effective if the local story line "translates" in a convincing way the underlying universal values or theme. Hence, in order to cross the national and cultural borders successfully, the "arguments" shall have to be convincing to the international and intercultural audience. Consequently, the convincing effect of the argument shall not only depend on the theme or values, but also on the rhetorically effective form (cf. Chatman (1990) mentioned above) of the narration. A study of the international and cross-cultural potential of filmic stories would do well to consider the role of language next to these types of parameters.

\section{Rhetorical features and types of "translation"?}

Where is then the link with the possible types of "translation"? Previous research in so-called polysystem (PS) studies has shown that translations, adaptations or remakes, when considered in larger corpora, often fulfil specific functions within their respective target context(s) (PS2). In other words, the target oriented PS approach has shown 
that for some types of "translation," target context conditions play an important role. For example, when dealing with some American films noirs of the 1940's and 1950's, I have noticed that the film adaptations of the corresponding "noir" literature helped to renovate the filmic genre in that period (cf. Cattrysse 1992). Hence, to be acceptable within the target context (PS2), the so-called source text (T1) has to fulfil a number of conditions; it has to present a number of features. If we consider a PS2 of mainstream, successful storytelling, one condition could be: success in the home context. In as far as the presence of effective rhetorical devices co-determines the success of a narrative, it may co-determine the decision to export or not the source text in one form or another (e.g. subtitled, dubbed or as a remake).

The choice for one type of translation rather than another (e.g. subtitling, dubbing or remake, or the decision to ignore the $\mathrm{T} 1$ all together) is often determined by the distance between the characteristics of the T1's and the ruling conventions and expectations within the PS2(s). Therefore, it would be interesting to verify the following hypotheses:

- If the rhetorical form (cf. Chatman 1990) corresponds more or less with the PS2 conditions, the T1's may be imported into the PS2 through subtitling and/or dubbing.

- If however, the use of rhetorical devices deviates too much from the PS2 expectations, but its theme and premise are acceptable, PS2 decision makers may decide to remake the T1.

- If the distance between the T1 and the PS2 conditions is too large on the levels of rhetorical devices, theme and premise, PS2 decision makers may decide not to import the $\mathrm{T} 1$ and to ignore it all together ("zero-translation").

A comparative study of the respective functions of the remake, the subtitled and/ dubbed T2 and the zero-translation within a particular historical context, could enlighten us on the relative importance of the various parameters with respect to the general translation policy within that specific time-space context. Also, as stated above, a comparative study of these parameters and the use of language could determine the relative importance of the latter in the international and cross-cultural functioning of filmic narratives.

\section{Conclusion}

When considering the parameters inhibiting European movies from functioning successfully across national and cultural borders, linguistic diversity in Europe is not necessarily the most important handicap. It would seem that the effective use of some specific rhetorical devices might overcome this "obstacle" and offer a much more powerful tool to communicate successfully in an international and intercultural way.

I want to repeat that the narrative view taken here is necessarily a partial one. For convenience's sake, I label the working field of the screenwriter the narrative, that is plot, character, setting and theme. If at this narrative level, these features are not at all present or not applied in an efficient way, other devices can compensate at other levels and create other types of aesthetic pleasure. This is why an audience can still appreciate narratives without strong rhetorical devices.

At the same time, this consideration hints at an important epistemological problem. How are we to study the isolated impact of rhetorical devices on the narrative 
level with or without studying the effects of other devices at other levels? This is not a new problem. For example, it is well known in multimedia marketing campaigns. How can companies distinguish the marketing effects of separate media messages when applied in an integrated multimedia campaign? On many occasions, I have pleaded for an interdisciplinary and multidisciplinary approach (Cattrysse, 1997; 2002). Here again, it seems obvious that making enquiries into other disciplines helps to detect common problems, and maybe, to find common solutions. I know this type of research goes against some established, conservative disciplines. I already mentioned the problem of some scholars imprisoned within their intradisciplinary faculty walls, preventing them from considering for instance real audiences (cf. supra). In this type of research, so-called content experts (such as literary scientists, narratologists) shall have to work together with statistically trained experts as well as psychologists, cognitive scientists, neuro-biologists and various other experts (cf. supra). This will imply that also in the field of so-called "human arts," multidisciplinary teams of researchers shall have to collaborate intensively. Needless to say, such an approach would considerably enhance the chances to discover interesting new grounds.

\section{NOTES}

1. BSAC/MBS Seminar Report 1992 The Challenge of Language in European Film, Madrid, Media Business School.

2. Italics are mine.

3. At the end of his chapter, he quickly adds one filmic example though, Antonioni's Professione Reporter (Chatman 1990:ibid.)

4. Although current cultural studies has abandoned the oversimplifying binary distinction between "high" versus "low" or "popular" culture (see a.o. Vlasselaers-Baetens 1996; Baetens-Verstraete 2002), the binary opposition is still frequently maintained in "practitioner's" discourse, often for polemical reasons (cf. de Haes 1995).

5. The term spectacle refers to the sense of vision. Drama can produce aesthetic pleasure on the level of spectacle through its use of photography, composition of the image, colors, visuals, settings, costumes, visual atmosphere, etc. The term spectacle is used here in a technical, that is, a wider sense than the daily term spectacle, which refers only to a limited number of more spectacular items or events such as twisters, earthquakes, spectacular disasters, and the like.

6. That may be why recent marketing and distribution strategies try to avoid the un-controllable "word of mouth" publicity with respect to movies by showing them simultaneously in as many theatres as possible.

7. Whether they are rhetorical or narrative in nature remains an interesting though rather academic question. Chatman (1990:195) states indeed that no features are intrinsically rhetorical. Rather they are "narrative features that function rhetorically" (Chatman 1990:ibid.). A zero focalisation, an inner view or a flashback are not rhetorical per se. However, when used with a specific rhetorical purpose, they become rhetorical. I am not convinced that the all rhetorical devices can be reduced to narrative techniques that are used with a rhetorical purpose.

8. Premise refers to a similar underlying message that is expressed in an indirect way by the story line. The use of so-called high concept projects (as opposed to low concept) is also related to these strategies: "High concept is a film industry term that gets tossed around fairly frequently and seems to take on a variety of definitions. Basically, it means that the story idea alone is sufficient to attract an audience, regardless of casting, reviews, and word of mouth. [...] High concept movies are those whose titles, newspaper ads, or TV Guide descriptions convey the promise of sex, violence, humor, or (particularly in television) some hot or taboo subject (nuclear war, incest, AIDS, and so on) (Hauge 1991:25).

9. See also Hauge (1991:95). 


\section{REFERENCES}

Baetens, J. and G. Verstraete (eds.) (2002): Cultural Studies. Een inleiding, Nijmegen, Vantilt. BAL, M. (1999): Introduction to the Theory of Narrative, Toronto, University of Toronto Press.

Воотн, W. (1991): The Rhetoric of Fiction, London, Penguin Books.

Bordwell, D. (1991): Making Meaning. Inference and Rhetoric in the Interpretation of Cinema, London, Harvard University Press.

Cattrysse, P. (1992): Pour une théorie de l'adaptation filmique. Le film noir, Bern, Peter Lang.

Cattrysse, P. (1995): Handboek Scenarioschrijven, Leuven-Apeldoorn, Garant.

CAttrysse, P. (1997): “Audiovisual Translation and New Media," in Robert Hodgson, Jr. and Paul A. Soukup (eds.), From One Medium to Another. Basic Issues for Communicating the Bible in New Media, Kansas City, Sheed \& Ward and American Bible Society, pp. 45-67.

Cattrysse, P. (2002): “Media Translation: a plea for an interdisciplinary approach," Versus. Quaderni di studi semiotici, 85 ("Sulla traduzione intersemiotica"), pp. 251-270.

Chatman, S. (1990): Coming to Terms. The Rhetoric of Narrative in Fiction and Film, London, Cornell University Press.

De Haes, L. (1995): Cultuur is Oorlog. Over Elite - en Massacultuur, Groot-Bijgaarden, Globe.

Friedman, J. (2002): “On not writing only for yourself," ScriptWriter (5:5).

Hauge, M. (1991): Writing Screenplays that Sell, New York, Harper Collins Publishers.

Hesling, W. and J.-M. Peters (1985): Audiovisuele Retoriek, Louvain, Centre for Communication Studies.

JäCKeL, A. (2001): "Shooting in English? Myth or Necessity?" in Gambier Yves and Gottlieb Henrik (eds.), (Multi)Media Translation. Concepts, Practices and Research, Amsterdam/Philadelphia, John Benjamins, pp. 73-89.

Kearns, M. (1999): Rhetorical Narratology, London, University of Nebraska Press.

Kennedy, G. (1991): Aristotle, On Rhetoric. A Theory of Civic Discourse, Oxford, Oxford University Press.

Lucey, P. (1996): Story Sense. Writing Story and Script for Feature Films and Television, New York, McGraw-Hill Companies Inc.

McClelland, J. (1986): "Rhetoric" in Sebeok (1986:815-819).

McKee, R. (1997): Story. Substance, Structure, Style and the Principles of Screenwriting, New York, ReganBooks, Harper Collins Publishers.

Sebeok, T. A (1986): Encyclopedic Dictionary of Semiotics, Berlin-New York-Amsterdam, Mouton de Gruyter.

VAndaele, J. (ed.) (1999): Translation and the (Re)Location of Meaning. Selected Papers of the CETRA Research Seminars in Translation Studies 1994-1996, Leuven, CETRA.

Van Gorp, H., Ghesquiere, R., Delabastita, D. and J. Flamend (eds.) (1991), Lexicon van Literaire Termen. Stromingen en genres. Theoretische begrippen. Retorische procédés en stijlfiguren, Leuven, Wolters.

Vlasselaers, J. and J. Baetens (eds.) (1996): Handboek Culturele Studies. Concepten - Problemen Methoden, Leuven, Acco. 